\title{
You are what you eat: relative importance of diet, gut microbiota and nestmates for honey bee, Apis mellifera, worker health
}

\author{
Gina Retschnig ${ }^{1}$ (@), Johannes Rich ${ }^{1}$, Karl Crailsheim $^{2}$, Judith Pfister ${ }^{1}$, \\ Vincent Perreten ${ }^{3}$, Peter NeUmanN ${ }^{1,4}$ \\ ${ }^{1}$ Institute of Bee Health, Vetsuisse Faculty, University of Bern, Schwarzenburgstrasse 161, 3003 Bern, Switzerland \\ ${ }^{2}$ Institute of Biology, University of Graz, Universitätsplatz 2, 8010 Graz, Austria \\ ${ }^{3}$ Institute of Veterinary Bacteriology, Vetsuisse Faculty, University of Bern, Länggassstrasse 122, 3012 Bern, \\ Switzerland \\ ${ }^{4}$ Agroscope, Swiss Bee Research Centre, Schwarzenburgstrasse 161, 3003 Bern, Switzerland
}

Received 1 September 2020 - Revised 29 January 2021 - Accepted 10 February 2021

\begin{abstract}
In eusocial honey bees, Apis mellifera, diet, gut microbiota and nestmates can all contribute to the health of freshly emerged individual workers, but their relative importance for longevity and body weight is currently unknown. Here, we show that diet is most relevant, followed by gut microbiota and the presence of nestmates. Freshly emerged workers were randomly assigned to eight treatments (with or without honey/pollen, protein-substitute lactalbumin, antibiotic tetracycline and nestmates for $24 \mathrm{~h}$ ) and maintained under standardised laboratory conditions. Longevity and food consumption were measured daily and fresh body weight was assessed at day 7. The data show a significantly better survival and a higher body weight in workers supplied with honey/pollen. Survival was higher in the lactalbumin treatments compared to the ones restricted to sucrose only, but lower compared to those with honey/pollen, highlighting the importance of micronutrients. In contrast, antibiotic treatment had a significant negative effect on longevity and body weight, which may be explained by inactivated gut microbiota and/or toxicity of the antibiotics. There was no positive effect of nestmates, probably due to the short exposure period. In contrast, nestmates showed a negative effect on survival in antibiotic-treated workers, possibly by transmitting pathogens and antibiotic-induced gut dysbiosis. In conclusion, a macro- and micronutrient-rich diet appears to be the key to individual honey bee worker health. Providing an optimal diet and possibly gut microbiota appears to be a promising way to promote managed A. mellifera health.
\end{abstract}

\section{Apis mellifera / nutrition / gut microbiota / longevity / nestmates}

\section{INTRODUCTION}

Diet, gut microbiota and nestmates can all contribute to the health of freshly emerged individuals (Haydak 1970; Alaux et al. 2010; Brodschneider and Crailsheim 2010). Adult honey bees eat pollen/

Corresponding author: G. Retschnig,

gina.retschnig@vetsuisse.unibe.ch

Gina Retschnig and Johannes Rich contributed equally to this work.

Manuscript editor: Cedric Alaux bee bread and honey supplying them with essential macro- (i.e. carbohydrates, protein, lipids, water) and micronutrients (i.e. vitamins, minerals, secondary plant products, Winston 1991; Brodschneider and Crailsheim 2010). In particular, pollen quantity and diversity play a key role for body weight and longevity (e.g. Haydak 1937; Schmidt et al. 1987; Di Pasquale et al. 2013). Especially important for queens and drones, but also for workers, are nestmates providing nutrient-rich jelly via trophallaxis (e.g. Haydak 1970; Crailsheim 1991; Camazine et al. 1998). 
Gut microbiota may also play an important role for nutrition by contributing to fermentation of pollen to bee bread and by providing micronutrients (e.g. vitamins, Noda et al. 1994; Vásquez and Olofsson 2009; Martinson et al. 2012) as well as for host defence by producing bioactive substances against pathogens (Forsgren et al. 2010; Vásquez et al. 2012; Olofsson et al. 2016). Freshly emerged bees can acquire their microbiota through contact either with nurse bees and hive surfaces (e.g. worker faeces, Powell et al. 2014) or with older nestmates (Martinson et al. 2012). However, there are no data yet for the relative importance of diet, gut microbiota and the presence of nestmates for worker longevity and body weight.

One common approach to compensate inadequate pollen supply is protein substitutes, e.g. soybean, brewer's yeast (De Jong et al. 2009; Brodschneider and Crailsheim 2010) and skimmed milk powder (Paray et al. 2021) with lactalbumin being one main protein component (Bütikofer et al. 2006). The latter is also used in honey bee cell cultures (Bergem et al. 2006), because it contains all essential amino acids (De Groot 1953; Brew et al. 1970). However, at present, there are no data for comparing lactalbumin as a single substitute to natural diet (honey/pollen) and lack of proteins.

Here, we conducted a laboratory study to investigate the relative importance of diet, gut microbiota and nestmates on longevity and body weight of workers. These parameters are adequate tokens of health (De Jong et al. 1982; Farjan et al. 2012; Retschnig et al. 2014; Straub et al. 2019). We would expect longest survival and highest body weights in workers that have a nutrient-rich diet, nestmates present during emergence and an intact gut microbiota.

\section{MATERIAL AND METHODS}

\subsection{Experimental set-up}

The experiments were carried out from June to August 2017 at the Institute of Bee Health, Bern, Switzerland, and consisted of eight laboratory hoarding cage treatment groups (Table I). The queens of three local, unrelated colonies were caged on empty worker brood frames for $48 \mathrm{~h}$ to obtain defined age cohorts of freshly emerged adult workers. Twenty-four hours before the workers were expected to emerge (Human et al. 2013), the frames were taken out of the colonies and all workers on the brood frames were shaken into an empty Styrofoam box. They were mixed to randomise for the genetic background, sprayed with sugar water $(15 \% \mathrm{w} / \mathrm{v})$ and returned onto the frames ( $\sim 250$ workers per frame). To provide gut microbiota and essential nutrients to the treatment groups "nestmates", the frames with the nestmates were placed in cages and maintained in an incubator for $24 \mathrm{~h}$ at $34.5{ }^{\circ} \mathrm{C}$ and $\geq 50 \%$ relative humidity (RH) (Williams et al. 2013). Then, the freshly emerged workers were visually separated from their older nestmates ("fluffy" appearance, low movements and inability to fly, Winston 1991) and randomly added to 32 plastic hoarding cages ( $N=25$ each cage; Williams et al. 2013). To obtain the workers for the treatment groups "without nestmates", the frames were simply cleaned of all remaining workers prior to incubation.

\subsection{Antibiotic treatments and feeding regimes}

Tetracycline was used as broad-spectrum antibiotic to decrease the abundance of major gut bacteria such as Lactobacillus spp. and Bifidobacterium spp. (Raymann et al. 2017), despite its known possible toxic effects (Raymann and Moran 2018). Tetracycline was applied to the groups 4, 5, 6 and 7 (Table I) as a $1.5 \mathrm{ml}$ sterile $50 \%$ (w/v) sucrose solution containing $450 \mu \mathrm{g} / \mathrm{ml}$ tetracycline (tetracycline hydrochloride, SigmaAldrich, USA ) per cage and day (Raymann et al. 2017). The efficacy of the antibiotic treatment effect was confirmed by visual screening of a subsample of antibiotic-treated and control workers after $7(N=5-10$ each) and 14 days $(N=2-5$ each). The guts of these workers were plated and incubated under aerobic and anaerobic conditions (adapted from Jorgensen and Turnidge 2015). Then, the bacterial growth was visually recorded and substantially lower in the treated workers compared to the controls ( $\sim 50-90 \%$ lower; data not shown).

According to the treatment group (Table I), cages were supplied with one out of three feeding 
Table I. Treatment groups of the laboratory hoarding-cage experiment. Freshly emerged honey bee workers, Apis mellifera, received sucrose solution $(50 \% \mathrm{w} / \mathrm{v})$ and were either exposed to adult nestmates for $24 \mathrm{~h}$ after emergence or not (= nestmates), received the antibiotic tetracycline (= antibiotics), honey/pollen (honey/pollen) or lactalbumin paste (= lactalbumin) or not $(N=$ eight cages with 25 workers each for each treatment)

\begin{tabular}{|c|c|c|c|c|c|}
\hline \multirow[t]{2}{*}{ Group } & \multicolumn{4}{|l|}{ Treatment } & \multirow[b]{2}{*}{$N$} \\
\hline & Nestmates & Antibiotics & Honey/pollen & Lactalbumin & \\
\hline 1. Nestmates only & + & - & - & - & 200 \\
\hline 2. Nestmates, honey/pollen & + & - & + & - & 200 \\
\hline 3. Nestmates, lactalbumin & + & - & - & + & 200 \\
\hline 4. Antibiotics only & - & + & - & - & 200 \\
\hline 5. Antibiotics, honey/pollen & - & + & + & - & 200 \\
\hline 6. Antibiotics, lactalbumin & - & + & - & + & 200 \\
\hline 7. Nestmates, antibiotics & + & + & - & - & 200 \\
\hline 8. Control & - & - & - & - & 200 \\
\hline $\mathrm{N}$ total & & & & & 1600 \\
\hline
\end{tabular}

regimes: All workers received sterile sucrose solution $(50 \% \mathrm{w} / \mathrm{v}$, filtered through $0.45-\mu \mathrm{m}$ pore (Thermo Scientific ${ }^{T M}$ Nalgene ${ }^{T M}$ Rapid Flow ${ }^{T M}$, USA) ad libitum in a 2-ml syringe (Codan, Germany) (Williams et al. 2013). Treatment groups 2 and 5 were additionally fed with an unpasteurized honey/pollen paste consisting of a 2.33:1 ratio of pollen/honey using local products (organic multifloral pollen: Swiss Bio Pollen, Bienen Roth, Switzerland; honey: Swiss honey, $I B H)$. Treatment groups 3 and 6 received a lactalbumin paste (Standifer et al. 1960) as a protein substitute. The paste consisted of $20 \%$ (v) lactalbumin (Lactalbumin hydrolysate, Sigma-Aldrich, USA ), $69 \%$ powdered sugar and $11 \%$ water. Both pastes were stored at $-24{ }^{\circ} \mathrm{C}$ until defrosting shortly before use and were provided in $1.5 \mathrm{ml}$ microcentrifuge tubes. All devices with food were replaced every $24 \mathrm{~h}$ (Williams et al. 2013). The cages were kept in an incubator at 30 ${ }^{\circ} \mathrm{C}$ and $\geq 50 \% \mathrm{RH}$ for 21 days (Williams et al. 2013).

\subsection{Longevity, body weight and food consumption}

Mortality of the experimental workers was checked every $24 \mathrm{~h}$. Dead workers were recorded, removed from the cage and stored at $-20{ }^{\circ} \mathrm{C}$. To measure the fresh body weight, five randomly selected live workers were carefully removed from each cage on day 7, weighed (Mettler Toledo PR5003, $d=0.001 \mathrm{~g}$ ) and subsequently stored at $<-20{ }^{\circ} \mathrm{C}(N=40$ workers per treatment group) (Human et al. 2013). For food consumption, the consumed amount of sucrose solution was recorded by daily metering of the scale on the syringe. For the pastes (honey/pollen and lactalbumin), microcentrifuge tubes were weighed (Mettler Toledo PR5003, $d=0.001 \mathrm{~g}$ ) before administration and after replacement after $24 \mathrm{~h}$.

\subsection{Statistical analyses}

Data were tested for normality using the Kolmogorov-Smirnov test, revealing that body weight, consumption of sucrose solution, honey/ pollen and lactalbumin were not normally distributed. Body weight and food consumption were compared with Kruskal-Wallis one-way ANOVAs and Bonferroni multiple comparison tests. Spearman rank correlations were calculated for body weight and food consumption (sum of sucrose solution and paste consumption per bee for the first 7 days of the trial) as well as fresh body weight and median worker longevity. Overall and pairwise comparisons of paste consumption of the groups that were supplied with honey/pollen or lactalbumin were 
conducted with a Kruskal-Wallis ANOVA and Wilcoxon rank sum tests. Worker mortality was compared between groups with a Kaplan-Meier survival statistics using Log rank tests. For all statistical analyses, the NCSS software was used (NCSS Version 10, NCSS LLD, USA).

\section{RESULTS}

\subsection{Food consumption}

Sucrose solutionSucrose solution consumption differed significantly between treatments (KruskalWallis one-way ANOVA, $P<0.001$, Table II, Figure 1). Between treatments, which were supplied with both sucrose solution and paste (honey/pollen or lactalbumin), no significant differences in consumption of sucrose solution were observed (pairwise comparisons with Bonferroni multiple comparison test, $P \mathrm{~s}>0.05$ ). The groups, which have only received sucrose solution, showed a significantly higher consumption than the ones with antibiotic treatment in both groups with and without nestmates (Co vs. Ab; Nm vs. Nm/Ab, pairwise comparisons with Bonferroni multiple comparison test,
$P \mathrm{~s}<0.05)$. The groups supplied with honey/pollen or lactalbumin paste showed no significant difference in consumption of sucrose solution compared to those which have not received pastes $(\mathrm{Nm} / \mathrm{HP}$ vs. $\mathrm{Nm}$; Nm/LA vs. Nm; Ab/LA vs. Ab, pairwise comparisons with Bonferroni multiple comparison test, $P \mathrm{~s}>0.05)$, except for the antibiotic-treated group with the honey/pollen $\operatorname{diet}(\mathrm{Ab} / \mathrm{HP}$ vs. Ab, pairwise comparison with Bonferroni multiple comparison test, $P<0.05)$.

\section{Honey/pollen and lactalbumin consumption} There were no significant differences between the groups (Kruskal-Wallis ANOVA, $P>0.05$; Wilcoxon rank sum tests, all $P \mathrm{~s}>0.05$, Table II).

\subsection{Body weight}

The fresh body weights were significantly different between the treatments (Kruskal-Wallis one-way ANOVA, $P<0.001$, Figure 2). The highest body weights were observed in the groups, which have received honey/pollen, independent of nestmates and antibiotics (Bonferroni

Table II. Daily consumption of sucrose solution ( $\mu \mathrm{l} /$ worker), honey/pollen and lactalbumin paste consumption (mg/ worker) for the treatment groups. Medians and quartiles are shown

\begin{tabular}{|c|c|c|c|}
\hline \multirow[b]{2}{*}{ Group } & \multicolumn{3}{|l|}{ Treatment } \\
\hline & Lower quartile & Median & Upper quartile \\
\hline & \multicolumn{3}{|l|}{ Sucrose solution $[\mu 1 /$ worker] } \\
\hline 1. Nestmates & 25.42 & 33.33 & 44 \\
\hline 2. Nestmates, honey/pollen & 28.72 & 40 & 50 \\
\hline 3. Nestmates, lactalbumin & 21.83 & 30.77 & 40 \\
\hline 4. Antibiotics & 20 & 27.89 & 36 \\
\hline 5. Antibiotics, honey/pollen & 24 & 33.33 & 44.44 \\
\hline 6. Antibiotics, lactalbumin & 22.07 & 31.58 & 42.14 \\
\hline 7. Nestmates, antibiotics & 20 & 24 & 32 \\
\hline \multirow[t]{2}{*}{ 8. Control } & 33.33 & 40 & 50 \\
\hline & \multicolumn{3}{|l|}{ Honey/pollen paste [mg/worker] } \\
\hline 2. Nestmates, honey/pollen & 0 & 2.63 & 9.11 \\
\hline \multirow[t]{2}{*}{ 5. Antibiotics, honey/pollen } & 0 & 3.77 & 9.06 \\
\hline & \multicolumn{3}{|l|}{ Lactalbumin paste [mg/worker] } \\
\hline 3. Nestmates, lactalbumin & 0.29 & 3.46 & 7.31 \\
\hline 6. Antibiotics, lactalbumin & 0.01 & 3.38 & 6.55 \\
\hline
\end{tabular}




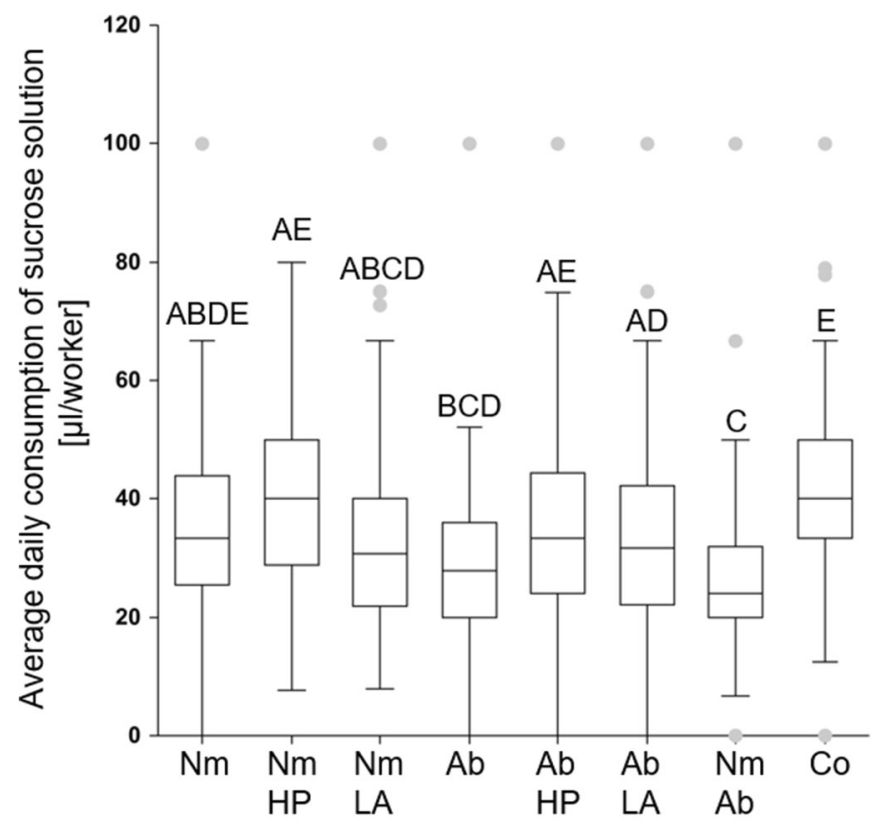

Treatment group

Figure 1. Average daily sucrose solution consumption of honey bee, Apis mellifera, workers in the treatments (nestmates (Nm), antibiotic (Ab), supply with honey/pollen (HP) or lactalbumin (LA) and controls (Co)) for the whole study duration (in $\mu 1 /$ worker/day). Significant differences between the groups (Bonferroni multiple comparison tests, $\left.P_{\mathrm{s}}<0.05\right)$ are indicated with different letters. The boxplots show interquartile ranges (boxes), medians (black lines within the interquartile range), data range (vertical lines) and outliers (grey dots).

multiple comparison test, all $P \mathrm{~s}<0.05)$. Workers from the groups, which have received honey/ pollen or lactalbumin, showed significantly higher body weights compared to workers without protein supply (Bonferroni multiple comparison tests, $P$ s $<0.05)$. While there was no significant difference between workers fed with honey/pollen or lactalbumin (Bonferroni multiple comparison test, $P \mathrm{~s}>0.05)$, protein diet with honey/pollen resulted in higher body weights compared to lactalbumin in the groups with antibiotic treatments and without nestmates (groups 5 (Ab, HP) and 6 (Ab, LA), Bonferroni multiple comparison test, $P \mathrm{~S}<0.05)$. Interestingly, antibiotic-treated workers showed lower body weights compared to workers without antibiotic treatment, only when nestmates were present (Bonferroni multiple comparison test, $P<0.05$ and $P \mathrm{~S}>0.05)$. Otherwise, the presence of nestmates had no significant effect (Bonferroni multiple comparison test, $P \mathrm{~s}>0.05$ ).

\subsection{Association of food consumption and worker body weight}

The total consumption of sucrose solution per worker of the experiment was significantly positively correlated with the individual body weight for the groups, which have only received sucrose solution (data pooled from all groups without paste supply: $\mathrm{Co}, \mathrm{Nm}, \mathrm{Ab}, \mathrm{Nm} / \mathrm{Ab}$, Spearman rank correlation coefficient $0.3486, P<0.001, N=160$, Figure 3a) and the groups, which have additionally received honey/pollen or lactalbumin (data pooled from all groups with paste supply: Nm/HP, Nm/LA, Ab/HP, $\mathrm{Ab} / \mathrm{LA}$, Spearman rank correlation $0.2101, P<0.01$, $N=160$, Figure $3 b$ ). If correlations of total consumption of sucrose solution and individual body weight were calculated separately for workers treated with or without antibiotics, significant correlations were only observed in the antibiotic-treated groups (groups without paste supply: Spearman rank 


\section{Worker body weight [g]}

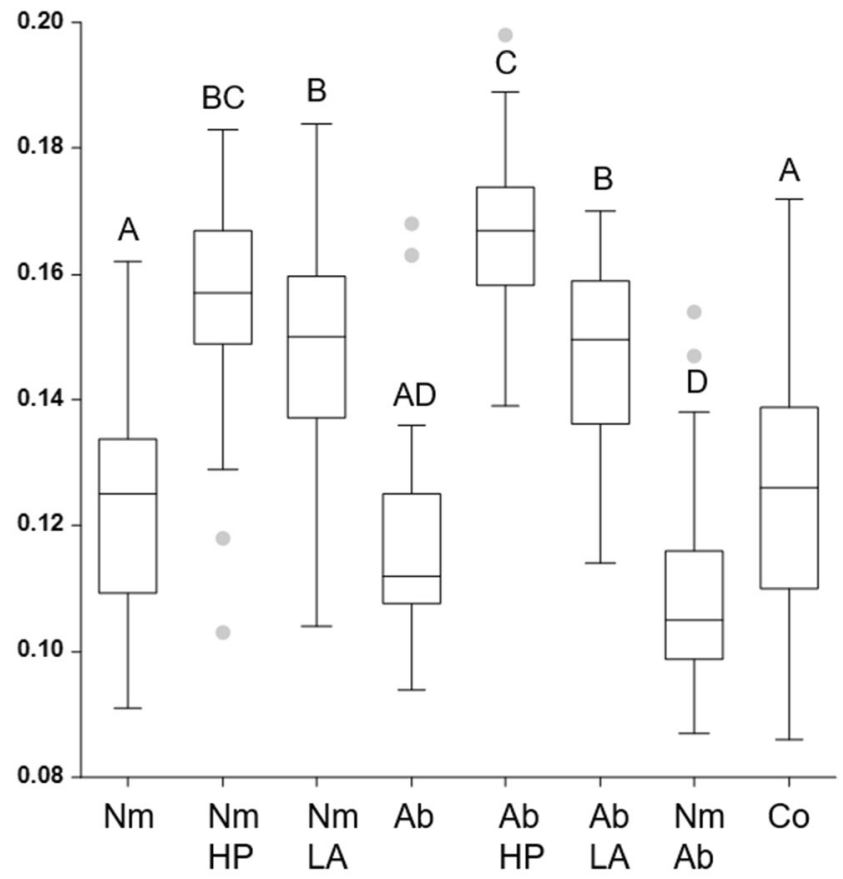

Treatment group

Figure 2. Honey bee, Apis mellifera, worker fresh body weight in the different treatment groups (measured in a subsample of $N=40$ workers per group on day 7). Treatments include groups with nestmates (Nm), antibiotic (Ab), supply with honey/pollen (HP) or lactalbumin (LA) and control (Co). The letters A-D mark significant differences based on Bonferroni multiple comparison tests, $P_{\mathrm{S}}<0.05$. The boxplots show interquartile range (box), median (black line within the interquartile range), data range (vertical lines) and outliers (grey dots).

coefficient $0.2712, P<0.05, N=80$; groups with paste supply: Spearman rank coefficient 0.2782 , $P<0.05, N=80)$. Similarly, a significant positive correlation was detected between the sum of paste consumption (days 1 to 7 ) and individual body weight (data pooled from all groups with paste supply: Nm/HP, Nm/LA, Ab/HP, Ab/LA, Spearman rank correlation coefficient $0.4696, P<0.001$, $N=160$, Figure 4).

\subsection{Longevity}

The workers, which received honey/pollen paste and were exposed to nestmates, showed a significantly better survival compared to all other groups (Kaplan-Meier, Log rank test, all $P \mathrm{~s}<0.05$,
Figure 5, Table III), followed by workers, which received lactalbumin and were exposed to nestmates, significantly living longer than all groups (Kaplan-Meier, Log rank test, $P<0.05$, Figure 5, Table III) except the former group, the one with antibiotics and honey/pollen and the controls (Kaplan Meier, Log rank test, $P$ s $>0.05$, Figure 5, Table III). The highest mortality occurred in bees exposed to nestmates and fed with antibiotics followed by the one exposed to antibiotics only (Kaplan-Meier, Log rank test, $P \mathrm{~s}<0.05$, Figure 5, Table III). The comparisons of the groups with different diets showed that workers, which received honey/pollen, survived significantly longer compared to those which received only sucrose solution or sucrose solution and lactalbumin in the groups with and without antibiotics 
Sum of sucrose solution consumption $[\mu l]$

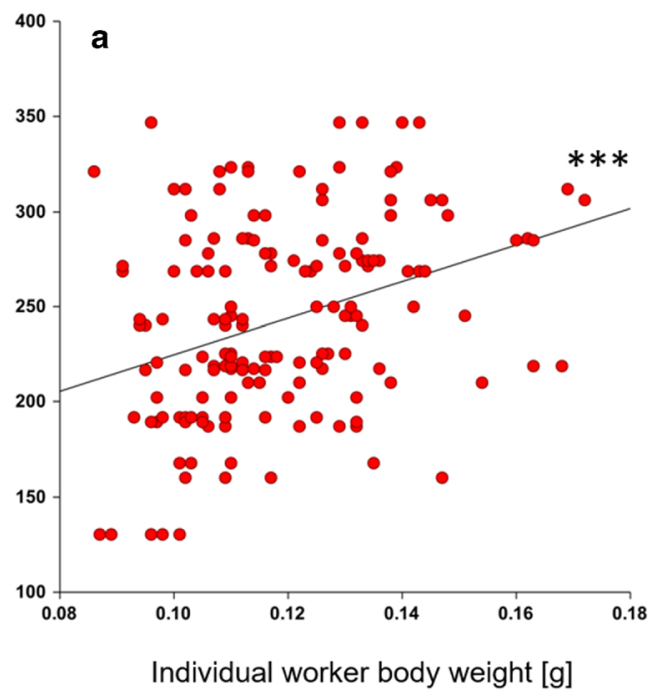

Sum of sucrose solution consumption $[\mu l]$

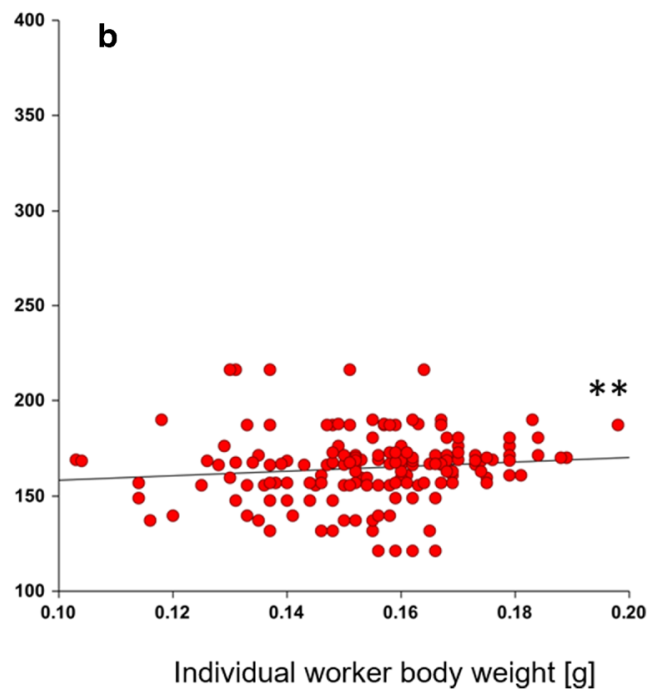

Figure 3. Significant positive correlation between the sum of sucrose consumption (days 1-7) and individual honey bee, Apis mellifera, body weight in workers that have received a sucrose solution only $(N=160$, Spearman rank correlation coefficient $0.3486, P<0.001$, level of significance $* * *=P<0.001)$ or $\mathbf{b}$ additionally honey/pollen or lactalbumin paste $(N=160$, Spearman rank correlation $0.2101, P<0.01$, level of significance $* *=P<0.01)$. Each dot represents one experimental worker.

(Nm/HP vs. Nm; Nm/HP vs. Nm/LA; Ab/HP vs. $\mathrm{Ab} ; \mathrm{Ab} / \mathrm{HP}$ vs. Ab/LA, Kaplan-Meier, Log rank test, $P \mathrm{~s}<0.05$, Table III). Similarly, workers from the groups without antibiotic treatment showed significantly higher longevity than groups with antibiotic treatment (Co vs. Ab; $\mathrm{Nm}$ vs. Nm/Ab; Kaplan-Meier, Log rank test, all $P_{\mathrm{S}}<0.05$, Figure 5, Table III). The presence of nestmates either had no significant impact on survival compared to the control group (Nm vs. Co, KaplanMeier, Log rank test, $P>0.05$ ) or resulted in a higher mortality, when the antibiotic was supplied (Nm/Ab vs. Ab, Kaplan-Meier, Log rank test, $P<0.05$, Figure 5, Table III).

\subsection{Body weight as predictive marker for longevity}

Body weight that was measured on day 7 in 40 workers per treatment showed a significant positive correlation with the median longevity during the whole duration of the study $(N=320$, Spearman rank correlation coefficient $0.2393, P<0.001$, Figure 6).

\section{DISCUSSION}

The data show that diet was the most important aspect for honey bee worker body weight and longevity, followed by gut microbiota and the presence of nestmates. Both significantly higher body weights and enhanced survival of workers were obtained with a honey/pollen or lactalbumin diet confirming earlier reports (e.g. Haydak 1970; Brodschneider and Crailsheim 2010; Wright et al. 2018). The honey/pollen diet led to better survival than the lactalbumin diet, while both of these diets were clearly superior to the one restricted to sucrose solution in terms of survival and body weight. Antibiotic-treated workers with an inactivated gut microbiota showed significantly higher mortality, unless they were supplied with a honey/pollen diet. The presence of nestmates during emergence of adult workers did increase neither body weights nor survival, but decreased survival in the antibiotic-treated workers.

The observed higher fresh body weights in the workers fed with a honey/pollen or lactalbumin diet compared to one restricted to sucrose are in 


\section{Sum of paste consumption [mg]}

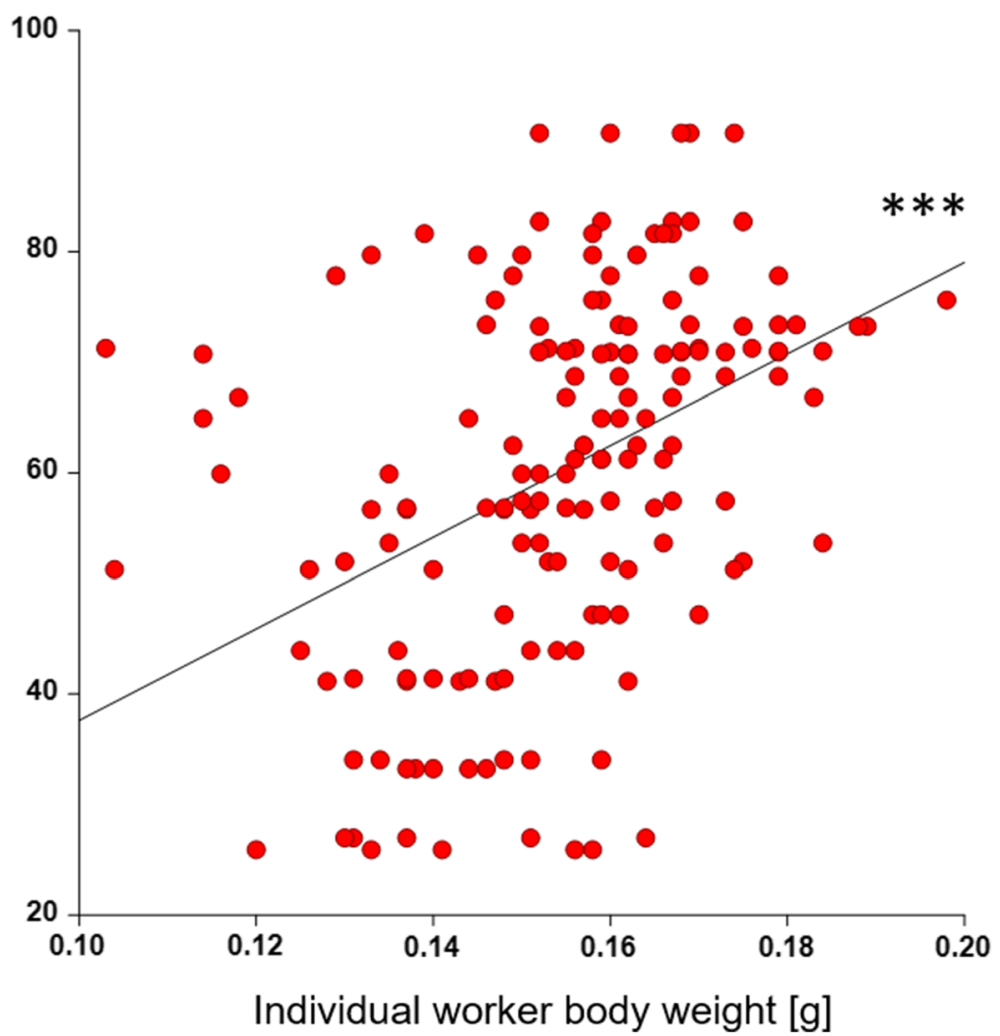

Figure 4. Significant positive correlation between the sum of paste consumption (days 1-7) and individual honey bee, Apis mellifera, fresh worker body weight ( $N=160$ on day 7, Spearman rank correlation coefficient 0.4696 , $P<0.001$, level of significance $* * *=P<0.001)$. Each dot represents one worker. The figure includes only workers from the treatments that have received honey/pollen (HP) or lactalbumin (LA) paste.

line with previous reports and are likely due to protein supply (e.g. Haydak 1937). The supply with protein has likely led to a better development of body tissues (e.g. fat body, muscle tissue), thereby resulting into higher body weights (Haydak 1970). The higher body weight of honey/pollen vs. lactalbumin fed workers may be explained by the presence of proteases, a better assimilation and additional nutrients in the honey/ pollen diet (i.e. organic acids, lipids, minerals, polyphenols, trace elements, vitamins and aroma compounds, Keller et al. 2005, Bogdanov et al. 2008, Campos et al. 2008). Surprisingly, workers that have received honey/pollen or lactalbumin paste consumed similar amounts of sucrose solution compared to workers that were restricted to sucrose only. This may be due to the ability of caged workers to self-regulate their intake at a rate of $\sim 10 \%$ of proteins and $\sim 90 \%$ of carbohydrates (Altaye et al. 2010), following the principle of nutritional self-selection (Waldbauer and Friedman 1991).

The importance of protein supply was further confirmed by our survival data. Indeed, survival was highest in the groups that have received honey/pollen, followed by lactalbumin and sucrose solution only. This is in line with previous reports of higher worker longevity when fed with proteinrich diets compared to low- or no-protein diets (Schmidt et al. 1987; Malone et al. 1999; Di Pasquale et al. 2013; Tritschler et al. 2017). However, the higher mortality in the workers fed with 


\section{Cumulative survival [\%]}

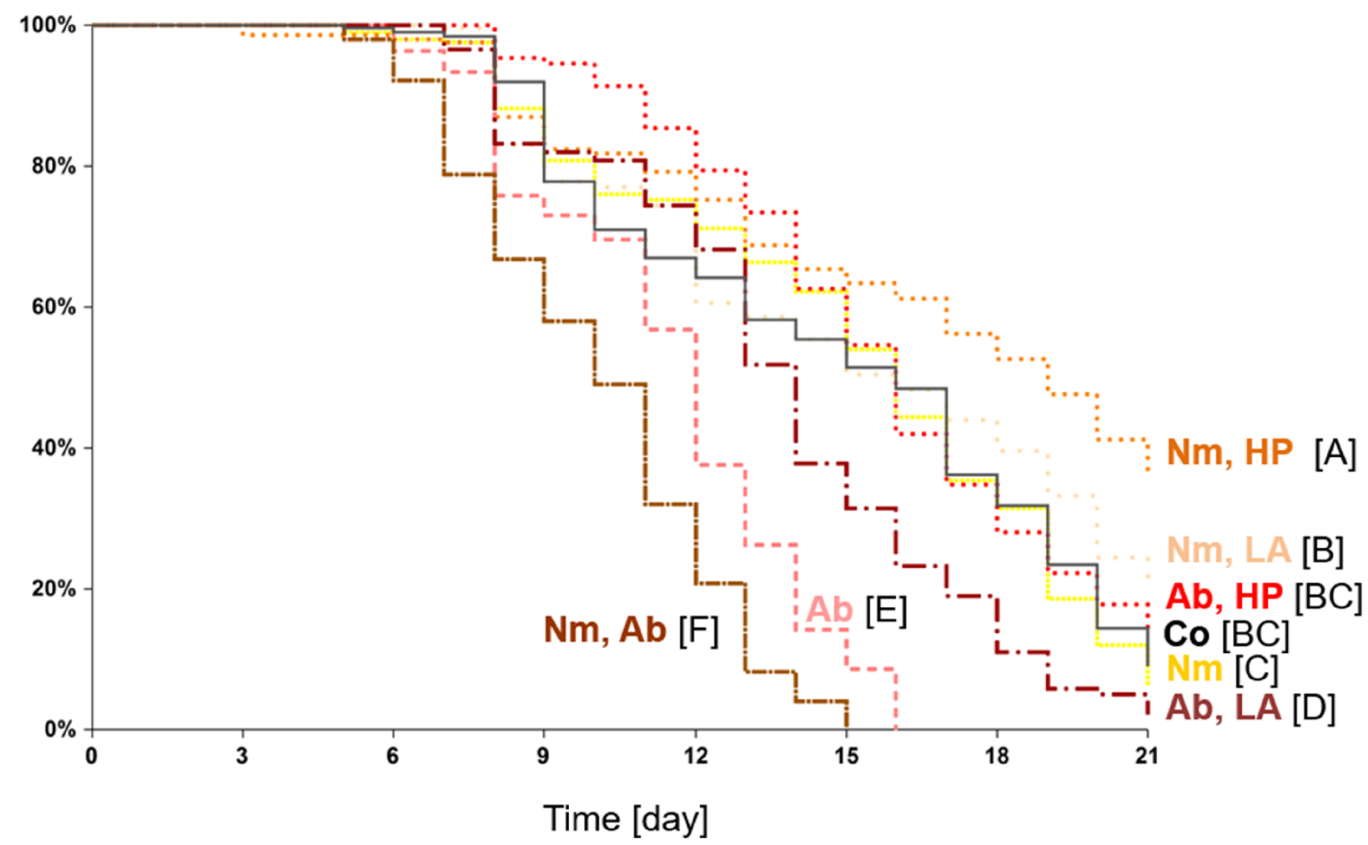

Figure 5. Honey bee, Apis mellifera, worker longevity in the eight treatment groups ( $N=200$ workers/group) with nestmates $(\mathrm{Nm})$, antibiotic (Ab), supply with honey/pollen (HP) or lactalbumin (LA) and control (Co). KaplanMeier survival curves are shown. The digits next to the curves indicate the treatment groups and different letters mark significant differences between the groups based on Log rank tests $(P \mathrm{~s}<0.05)$.

lactalbumin compared to the ones fed with honey/ pollen reveals that lactalbumin alone is not an adequate replacement. This is in line with earlier findings (Standifer et al. 1960) and may be due to the lack of additional nutrients (see above), a lower protein variation (Brew et al. 1970; Cremonz et al. 1998; Di Pasquale et al. 2013) and/or bio-availability (Standifer et al. 1960). In any case, the superior survival of the honey/pollen groups compared to the lactalbumin ones, despite the presence of all essential amino acids in both groups, supports the so far neglected importance of micronutrients for bee health (e.g. vitamins, minerals). It therefore appears as if these micronutrients deserve more attention if the aim is to provide managed bee health with an optimal diet, especially when routinely replacing diverse honey stores with sugar solutions (Neumann and Blacquière 2017).

Antibiotic treatment showed negative effects on both worker body weight and longevity. In the groups with nestmates being present, antibiotic-treated workers had lower body weights than the ones without antibiotic treatment, which is likely a consequence of the reduced food consumption. This is in line with negative effects of antibiotics on feeding in Daphnia magna (Gorokhova et al. 2015) and may be a result of lower hunger levels due to decreased activity and energy demand (Olaerts 1956; Winston 1991). Alternatively, but not mutually exclusive, the disrupted gut microbiota may be involved, because intact gut microbiota can promote weight gain in young workers (Zheng et al. 2017).

The clear negative impact of the antibiotic treatment on worker survival is also in line with previous reports (Raymann et al. 2017). This may be due to toxic effects of tetracycline (Ballard and Melvin 2007; Raymann and Moran 2018), inactivation of the gut microbiota (Vásquez and Olofsson 2009; Raymann et al. 2017), or further systemic reactions of the individuals, i.e. reduced 


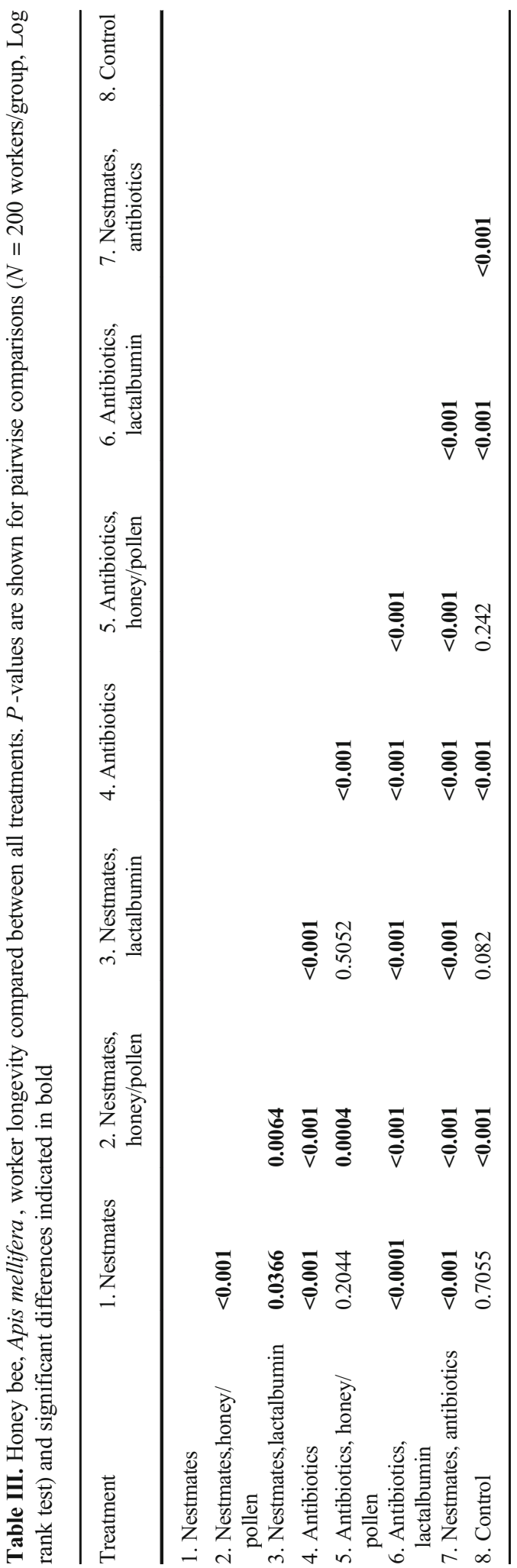




\section{Worker body weight $[g]$}

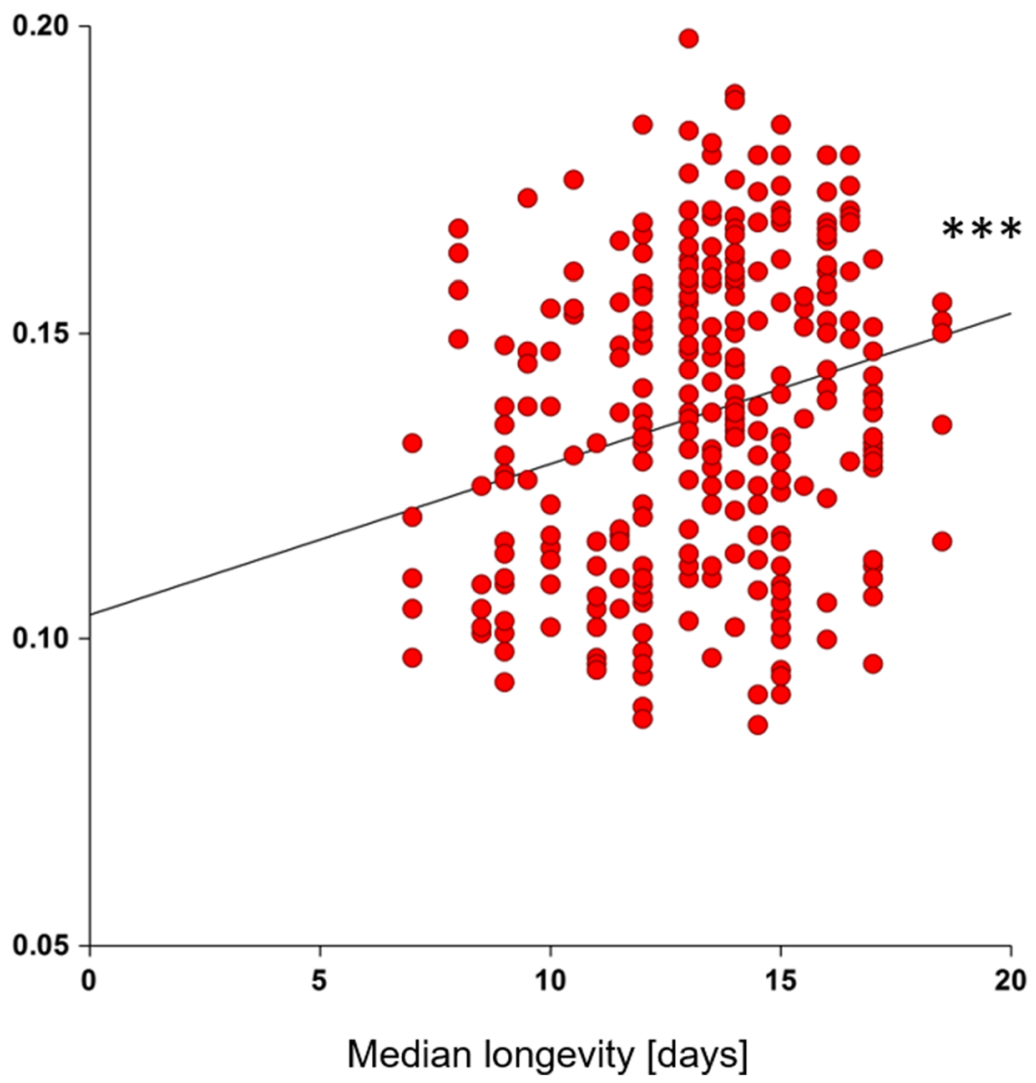

Figure 6. Significant positive correlation between honey bee, Apis mellifera, worker body weight measured on day 7 (all treatment groups combined, $N=40$ per treatment, total $N=320$ ) and median longevity (median value for each treatment, data from all experimental workers) during the whole duration of the cage study (22 days, Spearman rank correlation coefficient $0.2393, P<0.001$, level of significance $* * *=P<0.001$ ).

hunger levels. Interestingly, the antibiotic treatment did not decrease longevity when workers were supplied with the honey/pollen diet. Given that the tetracycline has a toxic effect, honey/ pollen may support detoxification by supplying proteins and phytochemical substances (e.g. $p$ coumaric acid; Mao et al. 2013; Schmehl et al. 2014; Berenbaum and Johnson 2015). In case the reduced survival partly results from the tetracycline-induced inactivation of the gut microbiota, the honey/pollen diet may compensate for certain beneficial effects of an intact gut microbiota, e.g. by supporting the immune system (Alaux et al. 2010) or providing essential nutrients such as b-vitamins (Noda et al. 1994; Vásquez and
Olofsson 2009). Alternatively, the negative effect of the antibiotic treatment may be stronger in pollen-deprived and therefore short-lived workers compared to longer-lived workers that obtained pollen in their diet. One important aspect that has not been addressed here is that access to pollen can considerably increase bacterial abundance in the gut, particularly in the ileum and rectum of honey bee workers (Ricigliano et al. 2017; Ricigliano and Simone-Finstrom 2020). In light of the numerous factors that influence abundance and diversity of the microbiota as well as the substantial effects the microbiota displays on various physiological processes in honey bees, more research is required. 
Overall, the presence of nestmates showed no positive effects on body weight and longevity. This is surprising, because the establishment of the gut microbiota requires the presence of nestmates or at least faecal material of workers with an established bacterial gut community (Powell et al. 2014; Hroncova et al. 2015). It has further been reported that workers that were isolated in laboratory cages show better physical development, when nestmates are present (Naiem et al. 1999). The positive effects of the nestmates may not suffice to alter the measured parameters. Alternatively, the limited time window of $24 \mathrm{~h}$ may not have been sufficient to provide the full potential benefit from exposed nestmates. Furthermore, emerging workers without nestmates may have obtained the required bacteria to establish their gut microbiota from alternative sources such as pollen from the brood frame shortly after emergence (Dietz 1969). However, the worst survival was observed in workers that were exposed to both antibiotics and nestmates. One potential explanation could be that the gut dysbiosis due to the antibiotic treatment facilitated the growth of opportunistic pathogens (Raymann et al. 2017), which could have been transmitted by the nestmates (e.g. Moeckel et al. 2011). Moreover, the workers may have been weakened already by tetracycline (see above). In general, the apparent lack of data on the role of nestmates in honey bee nutrition calls for more investigations.

Body weight has repeatedly been measured as an indicator for health in various studies on honey bees (e.g. Bowen-Walker and Gunn 2001; Retschnig et al. 2014), bumble bees (Holm 1972) and solitary bees (Tepedino and Torchio 1982). Obviously, food consumption is closely associated with body weight and likely plays an important role for worker longevity. However, in sharp contrast to food consumption, fresh body weight can be easily determined and therefore appears to constitute a simple token of health. Indeed, the data confirm the positive association of higher fresh body weight and longevity in honey bee workers, which underlines the suitability of this parameter as a valid predictive marker of honey bee health.

In conclusion, our data confirm that diet plays the key role for body weight and longevity. This is of high practical relevance, as providing sufficient and nutrient-rich food is one of the crucial elements of modern beekeeping management (Dolezal and Toth 2018; Sperandio et al. 2019). In light of unsustainable high colony losses (Neumann and Carreck 2010), adequate full nutritional supply, incl. micronutrients, therefore constitutes a key element for improving managed honey bee health.

\section{ACKNOWLEDGEMENTS}

The authors are most grateful to Cédric Alaux, who provided substantial constructive comments. Financial support was granted by Ricola Foundation Nature and Culture (GR, PN) and the Vinetum Foundation (PN). The COLOSS network provided the platform for cooperation between the collaborating authors.

\section{AUTHOR CONTRIBUTION}

GR, JR, VP, KC and PN designed and GR and JR conducted the experiment; GR, JR and JP analysed the data; GR and PN wrote the manuscript; VP, KC, JP and JR revised and approved the final manuscript.

\section{FUNDING}

Open Access funding provided by Universität Bern. Financial support was granted by Ricola Foundation Nature and Culture (GR, PN) and the Vinetum Foundation (PN).

\section{DATA AVAILABILITY}

The raw data of the study are available at the Dryad repository: https://doi.org/10.5061/dryad. tb2rbnzz6

\section{CODE AVAILABILITY}

Not applicable

\section{DECLARATIONS}

Ethics approval No approval of research ethics committees was required to accomplish the goals of this study because experimental work was conducted with an unregulated invertebrate species. 
Consent for publication All authors have read and approved the manuscript.

Conflict of interest The authors declare no competing interests.

\section{OPEN ACCESS}

This article is licensed under a Creative Commons Attribution 4.0 International License, which permits use, sharing, adaptation, distribution and reproduction in any medium or format, as long as you give appropriate credit to the original author(s) and the source, provide a link to the Creative Commons licence, and indicate if changes were made. The images or other third party material in this article are included in the article's Creative Commons licence, unless indicated otherwise in a credit line to the material. If material is not included in the article's Creative Commons licence and your intended use is not permitted by statutory regulation or exceeds the permitted use, you will need to obtain permission directly from the copyright holder. To view a copy of this licence, visit http://creativecommons. org/licenses/by/4.0/.

Vous êtes ce que vous mangez : importance relative de l'alimentation, du microbiote intestinal et des membres de la colonie pour la santé des ouvrières de l'abeille domestique Apis mellifera .

Apis mellifera / nutrition / flore intestinale / longévité / nourrice.

Du bist was du isst: verhältnismäßige Bedeutung von Ernährungsweise, Darmflora und Nestgenossen für die Gesundheit der Arbeitsbienen der Honigbiene Apis mellifera .

Apis mellifera / Ernährung / Darmflora / Lebensdauer / Ammenbienen.

\section{REFERENCES}

Alaux C, Ducloz F, Crauser D, Le Conte Y (2010) Diet effects on honeybee immunocompetence. Biol. Lett. 6, 562-565. https://doi.org/10.1098/rsbl.2009.0986

Altaye SZ, Pirk CWW, Crewe RM, Nicolson SW (2010) Convergence of carbohydrate-biased intake targets in caged worker honeybees fed different protein sources.
J. Exp. Biol. 213 (19), 3311-3318. https://doi. org/10.1242/jeb.046953

Ballard JWO, Melvin RG (2007) Tetracycline treatment influences mitochondrial metabolism and mtDNA density two generations after treatment in Drosophila . Insect Mol. Biol. 16(6), 799-802. https://doi. org/10.1111/j.1365-2583.2007.00760.x

Berenbaum MR, Johnson RM (2015) Xenobiotic detoxification pathways in honey bees. Curr Opin Insect Sci 10, 51-58. https://doi.org/10.1016/j.cois.2015.03.005

Bergem M, Norberg K, Aamodt RM (2006) Long-term maintenance of in vitro cultured honeybee (Apis mellifera) embryonic cells. BMC Dev. Biol. 6(1), 17. https://doi.org/10.1186/1471-213X-6-17

Bogdanov S, Jurendic T, Sieber R, Gallmann P (2008) Honey for Nutrition and Health: A Review. J. Am. Coll. Nutr. 27 (6), 677-689. https://doi.org/10.1080 /07315724.2008.10719745

Bowen-Walker PL, Gunn A (2001) The effect of the ectoparasitic mite, Varroa destructor on adult worker honeybee (Apis mellifera) emergence weights, water, protein, carbohydrate, and lipid levels. Entomol Exp Appl 101 (3), 207-217. https://doi.org/10.1046/j.15707458.2001.00905.x

Brew K, Castellino FJ, Vanaman TC, Hill RL (1970) The Complete Amino Acid Sequence of Bovine $\alpha$-Lactalbumin. J. Biol. Chem. 245 (17), 4570-4582

Brodschneider R, Crailsheim K (2010) Nutrition and health in honey bees. Apidologie 41 (3), 278-294. https://doi. org/10.1051/apido/2010012

Bütikofer U, Meyer J, Rehberger B (2006) Determination of the percentage of alpha-lactalbumin and betalactoglobulin of total milk protein in raw and heat treated skim milk. Milchwissenschaft. 61, 263-6

Camazine S, Crailsheim K, Hrassnigg N, Robinson EG, Leonhard B, Kropiunigg H (1998) Protein trophallaxis and the regulation of pollen foraging by honey bees (Apis mellifera L.). Apidologie 29(1-2), 113-126. https://doi.org/10.1051/apido:19980107

Campos MGR, Bogdanov S, de Almeida-Muradian LB, Szczesna T, Mancebo Y, Frigerio C, et al. (2008) Pollen composition and standardisation of analytical methods. J. Apic. Res. 47 (2), 154-161. https://doi. org/10.1080/00218839.2008.11101443

Crailsheim K (1991) Interadult feeding of jelly in honeybee (Apis mellifera L.) colonies. J. Comp. Physiol. B. 161, 55-60.

Cremonz TM, De Jong D, Bitondi MMG (1998) Quantification of hemolymph proteins as a fast method for testing protein diets for honey bees (Hymenoptera: Apidae). J. Econ. Entomol. 91 (6), 1284-1289. https://doi.org/10.1093/jee/91.6.1284

De Groot AP (1953) Protein and amino acid requirements of the honeybee (Apis mellifica L.). Physiol Comp Oecol 3, 197-285.

De Jong D, De Jong PH, Gonçalves LS (1982) Weight Loss and Other Damage to Developing Worker Honeybees from Infestation with Varroa Jacobsoni. J. Apic. Res. 
21 (3), 165-167. https://doi.org/10.1080 /00218839.1982.11100535

De Jong D, da Silva JE, Kevan PG, Atkinson JL (2009) Pollen substitutes increase honey bee haemolymph protein levels as much as or more than does pollen. J. Apic. Res. 48 (1), 34-37. https://doi.org/10.3896 /IBRA.1.48.1.08

Di Pasquale G, Salignon M, Le Conte Y, Belzunces LP, Decourtye A, Kretzschmar A, et al. (2013) Influence of Pollen Nutrition on Honey Bee Health: Do Pollen Quality and Diversity Matter? PLoS One 8(8), e72016. https://doi.org/10.1371/journal.pone.0072016

Dietz A (1969) Initiation of Pollen Consumption and Pollen Movement Through the Alimentary Canal of Newly Emerged Honey Bees. Ann. Entomol. Soc. Am. 62 (1), 43-46. https://doi.org/10.1093/aesa/62.1.43

Dolezal AG, Toth AL (2018) Feedbacks between nutrition and disease in honey bee health. Curr Opin Insect Sci 26, 114-9. https://doi.org/10.1016/j.cois.2018.02.006

Farjan M, Dmitryjuk M, Lipiński Z, Biernat-Łopieńska E, Żółtowska K. (2012) Supplementation of the honey bee diet with vitamin C: The effect on the antioxidative system of Apis mellifera carnica brood at different stages. J. Apic. Res. 51 (3), 263-270. https://doi. org/10.3896/IBRA.1.51.3.07

Forsgren E, Olofsson TC, Vásquez A, Fries I (2010) Novel lactic acid bacteria inhibiting Paenibacillus larvae in honey bee larvae*. Apidologie 41, 99-108. https://doi. org/10.1051/apido/2009065

Gorokhova E, Rivetti C, Furuhagen S, Edlund A, Ek K, Breitholtz M (2015) Bacteria-Mediated Effects of Antibiotics on Daphnia Nutrition. Environ. Sci. Technol. 49 (9), 5779-5787. https://doi.org/10.1021/acs.est.5 b00833

Haydak MH (1937) Changes in weight and nitrogen content of adult worker bees on a protein-free diet. J. Agric. Res. 54, 791-796.

Haydak MH (1970) Honey Bee Nutrition. Annu. Rev. Entomol. 15, 143-156. https://doi.org/10.1146 /annurev.en.15.010170.001043

Holm SN (1972) Weight and Life Length of Hibernating Bumble Bee Queens (Hymenoptera: Bombidae) under Controlled Conditions. Insect Syst Evol 3 (4), 313320. https://doi.org/10.1163/187631272X00184

Hroncova Z, Havlik J, Killer J, Doskocil I, Tyl J, Kamler M, et al. (2015) Variation in Honey Bee Gut Microbial Diversity Affected by Ontogenetic Stage, Age and Geographic Location. PLoS One 10 (3), e0118707. https://doi.org/10.1371/journal.pone.0118707

Human H, Brodschneider R, Dietemann V, Dively G, Ellis JD, Forsgren E, et al. (2013) Miscellaneous standard methods for Apis mellifera research. J. Apic. Res. 52 (4), 1-53. https://doi.org/10.3896/IBRA.1.52.4.10

Jorgensen J, Turnidge J (2015) Susceptibility Test Methods: Dilution and Disk Diffusion Methods*. In Jorgensen J, Pfaller M, Carroll K, Funke G, Landry M, Richter S, Warnock D (ed), Manual of Clinical Microbiology, 11th: 1253-1273. ASM Press, Washington. https://doi.org/10.1128/9781555817381.ch71
Keller I, Fluri P, Imdorf A (2005) Pollen nutrition and colony development in honey bees: part 1 . Bee World 86 (1), 3-10. https://doi.org/10.1080/0005772 X.2005.11099641

Malone AL, Burgess PE, Stefanovic D (1999) Effects of a Bacillus thuringiensis toxin, two Bacillus thuringiensis biopesticide formulations, and a soybean trypsin inhibitor on honey bee (Apis mellifera L.) survival and food consumption. Apidologie 30 (6), 465-473. https://doi.org/10.1051/apido:19990601

Mao W, Schuler MA, Berenbaum MR (2013) Honey constituents up-regulate detoxification and immunity genes in the western honey bee Apis mellifera. Proc. Natl. Acad. Sci. 110 (22), 8842-8846. https://doi. org/10.1073/pnas. 1303884110

Martinson VG, Moy J, Moran NA (2012) Establishment of characteristic gut bacteria during development of the honeybee worker. Appl. Environ. Microbiol. 00992240 (12), 2830-2840. https://doi.org/10.1128 /AEM.07810-11

Moeckel N, Gisder S, Genersch E (2011) Horizontal transmission of deformed wing virus: pathological consequences in adult bees (Apis mellifera) depend on the transmission route. J Gen Virol 92 (2), 370-377. https://doi.org/10.1099/vir.0.025940-0

Naiem ES, Hrassnigg N, Crailsheim K (1999) Nurse bees support the physiological development of young bees (Apis mellifera L.). J. Comp. Physiol. B. 169, 271279.

Neumann P, Blacquière T (2017) The Darwin cure for apiculture? Natural selection and managed honey bee health. Evol. Appl. 10, 226-230. https://doi. org/10.1111/eva.12448

Neumann P, Carreck NL (2010) Honey bee colony losses. J. Apic. Res. 49, 1. https://doi.org/10.3896 /ibra.1.49.1.01

Noda H, Akasaka N, Ohsugi M (1994) Biotin Production by Bifidobacteria. J. Nutr. Sci. Vitaminol. 40 (2), 181188. https://doi.org/10.3177/jnsv.40.181

Olaerts E (1956) Der Stoffwechsel der Bienen in Beziehung zu deren Aktivität und Temperatur. Proc XVI Int Beekeep Congr Vienna 16, 70.

Olofsson TC, Butler È, Markowicz P, Lindholm C, Larsson L, Vásquez A (2016) Lactic acid bacterial symbionts in honeybees - an unknown key to honey's antimicrobial and therapeutic activities. Int. Wound J. 13(5), 668679. https://doi.org/10.1111/iwj.12345

Paray BA, Kumari I, Hajam YA, Sharma B, Kumar R, Albeshr MF, Farah MA, Khan JM (2021) Honeybee nutrition and pollen substitutes: A review. Saudi J Biol Sci 28 (1), 1167-1176. https://doi.org/10.1016/j. sjbs.2020.11.053

Powell JE, Martinson VG, Urban-Mead K, Moran NA (2014) Routes of acquisition of the gut microbiota of the honey bee Apis mellifera. Appl. Environ. Microbiol. 80 (23), 7378-7387. https://doi. org/10.1128/AEM.01861-14

Raymann K, Moran NA (2018) The role of the gut microbiome in health and disease of adult honey bee 
workers. Curr Opin Insect Sci 26, 97104 . http://www.sciencedirect. com/science/article/pii/S2214574517301761. Accessed 14 July 2020

Raymann K, Shaffer Z, Moran NA (2017) Antibiotic exposure perturbs the gut microbiota and elevates mortality in honeybees. PLoS Biol. 15(3), e2001861. https://doi.org/10.1371/journal.pbio.2001861

Retschnig G, Williams GR, Mehmann MM, Yañez O, De Miranda JR, Neumann P (2014) Sex-specific differences in pathogen susceptibility in honey bees (Apis mellifera). PLoS One 9(1), e85261. https://doi. org/10.1371/journal.pone.0085261

Ricigliano VA, Simone-Finstrom M (2020) Nutritional and prebiotic efficacy of the microalga Arthrospira platensis (spirulina) in honey bees. Apidologie 51, 898-910. https://doi.org/10.1007/s13592-020-007705

Ricigliano VA, Fitz W, Copeland DC, Mott BM, Maes P, Floyd AS, Dockstader A, Anderson KE (2017) The impact of pollen consumption on honey bee (Apis mellifera ) digestive physiology and carbohydrate metabolism. Arch. Insect Biochem. Physiol. 96, e21406.

Schmehl DR, Teal PEA, Frazier JL, Grozinger CM (2014) Genomic analysis of the interaction between pesticide exposure and nutrition in honey bees (Apis mellifera). J. Insect Physiol. 71 , 177-190. https://doi.org/10.1016 /j.jinsphys.2014.10.002

Schmidt JO, Thoenes SC, Levin MD (1987) Survival of Honey Bees, Apis mellifera (Hymenoptera: Apidae), Fed Various Pollen Sources. Ann. Entomol. Soc. Am. 80 (2), 176-183. https://doi.org/10.1093/aesa/80.2.176

Sperandio G, Simonetto A, Carnesecchi E, Costa C, Hatjina F, Tosi S, Gilioli G (2019) Beekeeping and honey bee colony health: A review and conceptualization of beekeeping management practices implemented in Europe. Sci. Total Environ. 696, 133795. https://doi. org/10.1016/j.scitotenv.2019.133795

Standifer LN, McCaughey WF, Todd FE, Kemmerer AR (1960) Relative Availability of Various Proteins to the Honey Bee1. Ann. Entomol. Soc. Am. 53 (5), 618-25. https://doi.org/10.1093/aesa/53.5.618

Straub L, Williams GR, Vidondo B, Khongphinitbunjong K, Retschnig G, Schneeberger A, et al. (2019) Neonicotinoids and ectoparasitic mites synergistically impact honeybees. Sci. Rep. 9, 8159. https://doi. org/10.1038/s41598-019-44207-1
Tepedino VJ, Torchio PF (1982) Phenotypic variability in nesting success among Osmia lignaria propinqua females in a glasshouse environment: (Hymenoptera: Megachilidae). Ecol Entomol 7 (4), 453-462. https://doi.org/10.1111/j.1365-2311.1982.tb00688.x

Tritschler M, Vollmann JJ, Yañez O, Chejanovsky N, Crailsheim K, Neumann P (2017) Protein nutrition governs within-host race of honey bee pathogens. Sci. Rep. 7 (1), 14988. https://doi.org/10.1038 /s41598-017-15358-w

Vásquez A, Olofsson TC (2009) The lactic acid bacteria involved in the production of bee pollen and bee bread. J. Apic. Res. 48(3), 189-195. https://doi.org/10.3896 /IBRA.1.48.3.07

Vásquez A, Forsgren E, Fries I, Paxton RJ, Flaberg E, Szekely L, Olofsson TC (2012) Symbionts as major modulators of insect health: Lactic acid bacteria and honeybees. PLoS One 7 (7). https://doi.org/10.1371 /annotation/3ac2b867-c013-4504-9e06-bebf3fa039d1

Waldbauer GP, Friedman S (1991) Self-Selection of Optimal Diets by Insects. Annu. Rev. Entomol. 36(1), 43-63. https://doi.org/10.1146/annurev.en.36.010191.000355

Williams GR, Alaux C, Costa C, Csáki T, Doublet V, Eisenhardt D, et al. (2013) Standard methods for maintaining adult Apis mellifera in cages under in vitro laboratory conditions. J. Apic. Res. 52 (1), 136. https://www.tandfonline.com/doi/full/10.3896 /IBRA.1.52.1.04. Accessed 03 July 2020

Winston ML (1991) The biology of the honey bee. Harvard University Press.

Wright GA, Nicolson SW, Shafir S (2018) Nutritional Physiology and Ecology of Honey Bees. Annu. Rev. Entomol. 63, 327-344. https://doi.org/10.1146 /annurev-ento-020117-043423

Zheng H, Powell JE, Steele MI, Dietrich C, Moran NA (2017) Honeybee gut microbiota promotes host weight gain via bacterial metabolism and hormonal signaling. Proc. Natl. Acad. Sci. 114 (18), 4775-4780. https://doi. org/10.1073/pnas. 1701819114

Publisher's note Springer Nature remains neutral with regard to jurisdictional claims in published maps and institutional affiliations. 